\section{Rate of Ammonium Uptake by Cranberry (Vaccinium macrocarpon Ait.) Vines in the Field is Affected by Temperature}

T.R. Roper ${ }^{1}$ and A.R. Krueger

Dept. of Horticulture, University of Wisconsin-Madison, 1575 Linden Drive, Madison, Wisconsin 53706

\section{C.J. DeMoranville}

University of Massachusetts, Cranberry Experiment Station, East Wareham, Massachusetts 02538

\section{N. Vorsa}

Rutgers University, Blueberry and Cranberry Research Center, Chatsworth, New Jersey 08019

\section{J. Hart and A.P. Poole}

Department of Crop and Soil Science, Oregon State University, Corvallis, Oregon 97331

Additional index words. fertilizer, nitrogen, ${ }^{15} \mathrm{~N}$

Abstract. Nitrogen fertilizer application is a universal practice among cranberry growers. Cranberries only use ammonium nitrogen sources. This study was undertaken to discover how quickly cranberries in the field would take up fertilizer-derived ammonium nitrogen. Ammonium sulfate labeled with ${ }^{15} \mathrm{~N}$ was applied in field locations in Oregon, Massachusetts, New Jersey, and Wisconsin. Samples of current season growth were collected daily for 7 days beginning 24 hours after fertilizer application. In all cases ${ }^{15} \mathrm{~N}$ was detectable in the plants from treated plots by $\mathbf{2 4}$ hours following application. Additional nitrogen was taken up for the next 3 to 5 days depending on the location. With the exception of Oregon, the maximum concentration of ${ }^{15} \mathrm{~N}$ was found by day 7 . Oregon was the coolest of the sites in this research. To determine a temperature response curve for $\mathbf{N}$ uptake in cranberry, cranberry roots were exposed to various temperatures in aeroponics chambers while vines were at ambient greenhouse temperatures. The optimum temperature for $\mathrm{N}$ uptake by cranberry vines was 18 to $24^{\circ} \mathrm{C}$. This research suggests that ammonium fertilizers applied by growers and irrigated into the soil (solubilized) are taken up by the plant within 1 day following application. Soil and root temperature is involved in the rate of $\mathrm{N}$ uptake.

Cranberries are commercially grown in beds of sand or soils high in organic matter content The soils are usually kept moist, but are well drained. Heavy rainfall events or sprinkling over several successive nights for frost protection has the potential ability to leach nutrients below the root zone.

Nitrogen $(\mathrm{N})$ is the most common nutrien element applied to cranberry beds. To optimize $\mathrm{N}$ application, growers need to know the correct form of $\mathrm{N}$ to apply, the best application method, how much fertilizer to apply, and when to apply $\mathrm{N}$ fertilizers.

Cranberries preferentially use $\mathrm{N}$ in the ammonium form (Greidanus et al., 1972), although they can take up nitrate $\mathrm{N}$ with concurrent uptake of ammonium N (Rosen et al., 1990).

Received for publication 21 Oct. 2002. Accepted for publication 9 June 2003. This research was partially supported by Ocean Spray Cranberries, Inc. We thank Joan Davenport for valuable help with the manuscript.

${ }^{1}$ To whom reprint requests should be addressed; e-mail trroper@wisc.edu.
Research has also shown that there is little to no activity of nitrate reductase (Greidanus et al., 1972; Smith, 1993), indicating that only ammonium $\mathrm{N}$ contributes to cranberry growth and development.

Nitrogen fertilizer is usually applied in a granular form to cranberry beds to obtain the lowest cost per unit of $\mathrm{N}$. Cranberries will absorb $\mathrm{N}$ through foliage, but not enough to supply $\mathrm{N}$ for plant growth and development (Smith 1993).

Significantresearch efforthas been expended to understand appropriate timing and rates for nitrogen fertilizer for different cranberry producing regions. Recent research has established that optimal $\mathrm{N}$ rates and timings vary between growing regions (Davenport, 1996). Nitrogen rate also varies between cranberry cultivars (DeMoranville, 1992; Davenport and Vorsa, 1999) and with crop production history (Hart et al., 1990). Hart et al. (1994) have shown that $\mathrm{N}$ has no effect on fruit set or yield during the year of application. Guidelines for $\mathrm{N}$ fertilizer management have recently been published (Davenport et al., 2000).
A key piece of information that was lacking was the lag time between fertilizer application and plant uptake and use. This research was developed to determine the length of time between $\mathrm{N}$ fertilizer application and presence in cranberry leaves and the effect of temperature on $\mathrm{N}$ uptake.

\section{Materials and Methods:}

Plots $(2 \times 2 \mathrm{~m})$ were established in commercial beds of 'Stevens' cranberries in Oregon, Massachusetts, New Jersey, and Wisconsin. Three treatments were imposed: 1) control (no $\mathrm{N}$ applied); 2) $\mathrm{N}$ applied (10.6 g non-labeled ammonium sulfate (Sigma, St. Louis, Mo.) per plot); and 3) labeled $\mathrm{N}$ applied (10.6 g ammonium sulfate enriched to 1 atom $\%$ with ${ }^{15} \mathrm{~N}$ (Isotec, Miamisburg, Ohio) per plot). The $\mathrm{N}$ rate for treatments 2 and 3 were equivalent to $5.6 \mathrm{~kg} \mathrm{~N} / \mathrm{ha}$, about one quarter of a typical annual application to bearing beds (Davenport et al., 2000). Fertilizer was dissolved in $4 \mathrm{~L}$ of water and spread evenly across each plot with a watering can immediately followed by an application of $20 \mathrm{~L}$ of water to wash any residual fertilizer off the foliage and into the soil. Each treatment was replicated four times in each growing region. Treatments were made when uprights showed $1.5 \mathrm{~cm}$ of new growth (roughneck to hook stage), a time of maximum $\mathrm{N}$ demand in cranberry. Plant tissue samples consisted of current season growth from about 25 uprights and were collected from each plot before fertilizer application and then daily for 7 days postfertilizer application as well as 14, 21 , and $\approx 60 \mathrm{~d}$ after $\mathrm{N}$ application.

All samples were allowed to air dry and were shipped to Wisconsin where the samples were oven dried $\left(50^{\circ} \mathrm{C}\right)$ and then ground to 80 mesh in a Wiley mill. Samples were analyzed for percent $\mathrm{N}$ and the atom $\%{ }^{15} \mathrm{~N}$ using dry combustion analysis (Bremner, 1996) with the combination of a Carlo Urba nitrogen analyzer (Milan, Italy) and a mass spectrometer (Tracer Mass; Crew, Cheshire, U.K.)

Values of N recovery from fertilizer (NFF) were calculated using the following equation adapted from Hauck and Bremner (1976): $\mathrm{NFF}=\left({ }^{15} \mathrm{~N}_{\text {natural abundance }}-\text { atom } \%{ }^{15} \mathrm{~N}\right)_{\text {tissue }}$ $\left({ }^{15} \mathrm{~N} \quad-\right.$ atom $\left.\%{ }^{15} \mathrm{~N}\right)$

Natural abundance of the tissue was determined by control and pretreatment samples. The natural abundance of unlabeled fertilizer was $0.366 \%$.

Data were analyzed by the SAS (Cary, NC) mixed procedure. The slopes of the lines for days 0 to 3 were determined for each treated plot and the slopes across states were compared.

Direct effects of root temperature on $\mathrm{N}$ uptake were studied in aeroponics (Peterson and Krueger, 1988). Cuttings of 'Stevens' cranberry vines were rooted in aerated water. When roots appeared the cuttings were transferred to the aeroponics chambers where the roots were sprayed every $15 \mathrm{~s}$ with modified Hoaglands solution. Once the cuttings had grown to have enough tissue to analyze, $\approx 8$ weeks, treatments were imposed. The root temperature in the aeroponics chambers can be modified from air temperature $\left(\approx 21^{\circ} \mathrm{C}\right)$. Roots were chilled per

HortScience Vol. 39(3) June 2004 
the treatments and held for $24 \mathrm{~h}$ while receiving the standard nutrient solution. After $24 \mathrm{~h}$ the nitrogen in the solution sprayed on roots was changed to ammonium sulfate depleted in ${ }^{15} \mathrm{~N}$ for $24 \mathrm{~h}$ while the treatment root temperature was maintained. Control plants were subjected to the same temperatures but were given ammonium sulfate that was not depleted in ${ }^{15} \mathrm{~N}$ (natural abundance ${ }^{15} \mathrm{~N}$ ). The vines were then separated and the tops and roots analyzed for ${ }^{15} \mathrm{~N}$ as described above. Individual plants were replicates. The data were subjected to ANOVA with LSD mean separation following a significant $F$ value.

\section{Results and Discussion}

The tissue ${ }^{15} \mathrm{~N}$ concentration in field plots before fertilizer application was equal to natural abundance $\left(0.366 \%{ }^{15} \mathrm{~N}\right)$. This is indicated as $0 \mathrm{~N}$ from fertilizer (NFF). That the ${ }^{15} \mathrm{~N}$ concentration in tissue from untreated plots and those treated with unlabeled fertilizer did not vary from natural abundance throughout the experimental period (Fig. 1) across all sites and all dates suggests no interplot contamination, thus ${ }^{15} \mathrm{~N}$ above natural abundance was assumed to be from the labeled fertilizer.

In plots treated with ${ }^{15} \mathrm{~N}$ labeled fertilizer, tissue NFF was above natural abundance within one day of fertilizer application (Fig 1). In Wisconsin and New Jersey NFF did no increase significantly from days 2 through 14 whereas in Massachusetts and Oregon NFF in the tissue steadily increased through day 6 or 7. The stability in NFF found in Wisconsin and New Jersey after day seven suggests that the maximum amount of the labeled fertilizer had been taken up by about day 5 or 6 . The steady increase in Oregon and Massachusetts suggests that all applied fertilizer from the single treatment application had not been taken up until day 14 or later. NFF at days 21 and 60 was higher than at day 7 for Oregon, with tissue NFF becoming comparable to concentrations in day 2 samples from New Jersey and Wisconsin. Massachusetts always had slightly lower NFF than in Wisconsin or New Jersey.

Cranberries are shallow rooted and the soils in this study were moist and porous, creating optimum conditions for fertilizer to reach the roots. That cranberries, a woody perennial, would take up and translocate $\mathrm{N}$ to the leaves in just one day was surprising. When ${ }^{15} \mathrm{~N}$ enriched fertilizer was applied to apples the label was found in leaves by $30 \mathrm{~d}$ after application (Aguirre et al., 2001).

To evaluate the influence of location (state) on the rate of ${ }^{15} \mathrm{~N}$ uptake, we compared the slopes of the lines for NFF from days 0 to 3 for each state. Two slopes, hence uptake rates, were found, with the higher rate in New Jersey and Wisconsin and the lower rate in Oregon and Massachusetts (Table 1). Since research has indicated that regional differences in ai temperature influence fruit mass gain (DeMoranville et al., 1996), we examined the relationship between air temperature and ${ }^{15} \mathrm{~N}$ uptake rate. Air temperature data at the time of ${ }^{15} \mathrm{~N}$ fertilizer application from weather stations near plots (10-km radius) were plotted agains NFF. The data indicate that New Jersey and Wisconsin were the warmest sites, with mean daily air temperatures during days 0 to 14 of 31 and $29^{\circ} \mathrm{C}$, respectively. Massachusetts and Oregon were cooler at 22 and $17{ }^{\circ} \mathrm{C}$, respectively during the same time period. The cooler conditions generally experienced in Oregon are likely the cause of the slower uptake of $\mathrm{N}$ in Oregon than in other growing areas (Fig. 1) The slope of the uptake curve for the first $3 \mathrm{c}$ is also lower in Oregon. The spring of 1998 was generally warm in Wisconsin and New Jersey, likely resulting in the higher uptake rates in these two states.

The aeroponics experiment demonstrated the pronounced effect of temperature on $\mathrm{N}$ uptake by cranberry vines. The optimum temperature for uptake of ammonium was $\approx 18$ to $24{ }^{\circ} \mathrm{C}$ (Table 2). The rate dropped off quickly

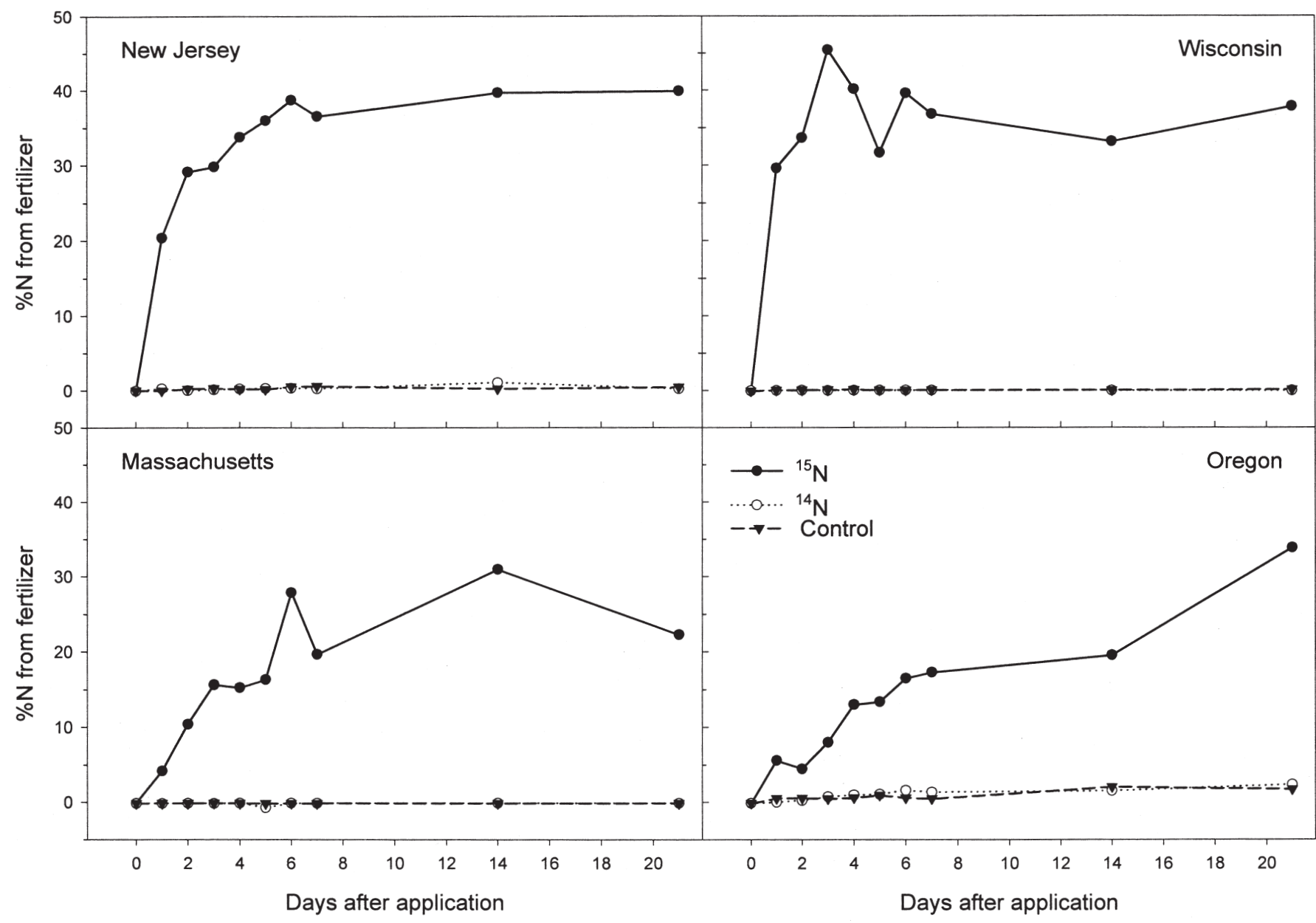

Fig. 1. Nitrogen uptake over time by cranberries in four locations in North America during 1998. In all cases the enriched ${ }^{15} \mathrm{~N}$ treatment was significantly different than the unfertilized control or the control fertilized with unlabeled fertilizer by day 1 of the experiment. All plots were at natural abundance ${ }^{15} \mathrm{~N}$ before treatment (0.366). Data shown are atom $\%, \mathrm{n}=4$. 
Table 1. Slopes of regression lines of days 0 to 3 for uptake of ${ }^{15} \mathrm{~N}$ by 'Stevens' cranberry vines in the field. The intercepts of the lines are all 0.366 atom $\%$.

\begin{tabular}{lc}
\hline State & Slope \\
\hline Oregon & $0.01456 \mathrm{a}^{2}$ \\
New Jersey & $0.09259 \mathrm{~b}$ \\
Massachusetts & $0.03519 \mathrm{a}$ \\
Wisconsin & $0.10700 \mathrm{~b}$ \\
\hline${ }^{2}$ Numbers followed by the same letter are not \\
different, determined by the SAS PROC MIXED \\
procedure.
\end{tabular}

procedure.

Table 2. Uptake of $\mathrm{N}$ fertilizer depleted in ${ }^{15} \mathrm{~N}$ by cranberry vines grown in aeroponics when roots had been subjected to $24 \mathrm{~h}$ of exposure to different temperatures. Control plants were exposed to the various temperatures, but were given nondepleted fertilizer, $\mathrm{n}=3$.

\begin{tabular}{lc}
\hline Root temp $\left({ }^{\circ} \mathrm{C}\right)$ & $\% \mathrm{~N}$ from fertilizer \\
\hline 4.5 & $1.658 \mathrm{a}^{\mathrm{z}}$ \\
7.2 & $2.505 \mathrm{~b}$ \\
12.7 & $3.643 \mathrm{c}$ \\
18.3 & $4.737 \mathrm{~d}$ \\
23.8 & $4.672 \mathrm{~d}$ \\
29.4 & $1.383 \mathrm{a}$ \\
Control & $0.358 \mathrm{e}$ \\
\hline${ }^{2}$ Mean separation by $p<0.05$ &
\end{tabular}

Mean separation by LSD, $p<0.05$

at warmer or cooler temperatures. These data also suggest that cranberry growers should wait until soil temperatures are at least 12.7 ${ }^{\circ} \mathrm{C}$ before applying $\mathrm{N}$ fertilizer. The average difference between the mean soil temperature at $5 \mathrm{~cm}$ and mean air temperature during the growing season (1 Apr. to 15 Oct.) was 0.45 ${ }^{\circ} \mathrm{C}$ over a 3 -year period (W. Bland, unpublished data). Therefore, over time, mean daily air temperature could be used as a proxy for soil temperature by growers to time fertilizer application.

It is clear from these data that $\mathrm{N}$ fertilizer becomes plant available in the root zone rapidly after application and that cranberries absorb and transport $\mathrm{N}$ quickly. However, it is important to remember that detected ${ }^{15} \mathrm{~N}$ only indicates presence and does not indicate if the detected $\mathrm{N}$ is in a soluble form or has been metabolically incorporated into amino acids, proteins or other compounds important for plant metabolism.

\section{Literature Cited}

Aguirre, P.B., Y.K. Al-Hinai, T.R. Roper, and A.R. Krueger. 2001. Apple tree rootstock and nitrogen fertilizer application timing affect nitrogen gen fertilizer application timing affect

uptake. HortScience 36:1202-1205.
Bremner, J.M. 1996. Nitrogen-Total.p. 1085-1122 In: J.M. Bigham (ed.). Methods of soil analysis. Part 3: Chemical methods. Soil Sci. Soc. Amer. Book Ser. 5. SSSA-ASA Press, Madison, Wis. Davenport, J.R. 1996. The effect of nitrogen fertilizer rates and timing on cranberry yield and fruit quality. J. Amer. Soc. Hort. Sci. 121(6):1089-1094.

Davenport, J., C. DeMoranville, J. Hart, and T. Roper. 2000. Nitrogen for bearing cranberries in North America. J. Hart (ed.). Ore. State Univ.
(Corvallis) Ext. Bul. EM 8741

Davenport, J.R., and N. Vorsa. 1999. Cultivar fruiting and vegetative response to nitrogen fertilizer in cranberry. J. Amer. Soc. Hort. Sci. 124(1):90-93.

DeMoranville, C.J. 1992.Cranberry nutrients, phenology, and N-P-K fertilization. PhD diss. Univ. Mass.-Amherst.

DeMoranville, C.J., J.R. Davenport, K. Patten, T. R. Roper, B.C. Strik, N. Vorsa, and A.P. Poole. 1996. Development of fruit mass in three cranberry cultivars and five production regions. J. Amer. Soc. Hort. Sci. 121(4):680-685.

Greidanus, T., L.A. Peterson, L.E. Schrader, and M.N. Dana. 1972. Essentiality of ammonium for cranberry nutrition. J. Amer. Soc. Hort Sci. 97:272--277.

Hart, J. M., A. Poole, K. L. Wilder, and B. C. Strik. 1990. Nitrogen rates and timing affect on cranberry yield and yield components. HortScience 25:1148 (abstr.)

Hart, J.,A.P. Poole, B.C. Strik, and N.W. Christensen. 1994. Nitrogen fertilizer rate and timing trials in Oregon. Proc. Wis. Cranberry School 5:18-22.

Hauk, R.D. and J.M Bremner. 1976. Use of tracer for soil and fertilizer nitrogen research. Adv. Agron. 28:219-266.

Peterson, L.A. and A. Krueger. 1988. An intermittent aeroponics system. Crop Sci. 28:712-713.

Rosen, C.J., D.L. Allen, and J.J. Luby. 1990. Nitrogen form and solution $\mathrm{pH}$ influence growth and nutrition of two Vaccinium clones. J. Amer. Soc. Hort. Sci. 115:83-89.

Smith, J.D. 1993. Uptake and utilization of nitrogen sources by cranberry plants (Vaccinium macrocarpon Ait.). PhD diss. Univ. Wis.-Madison. 